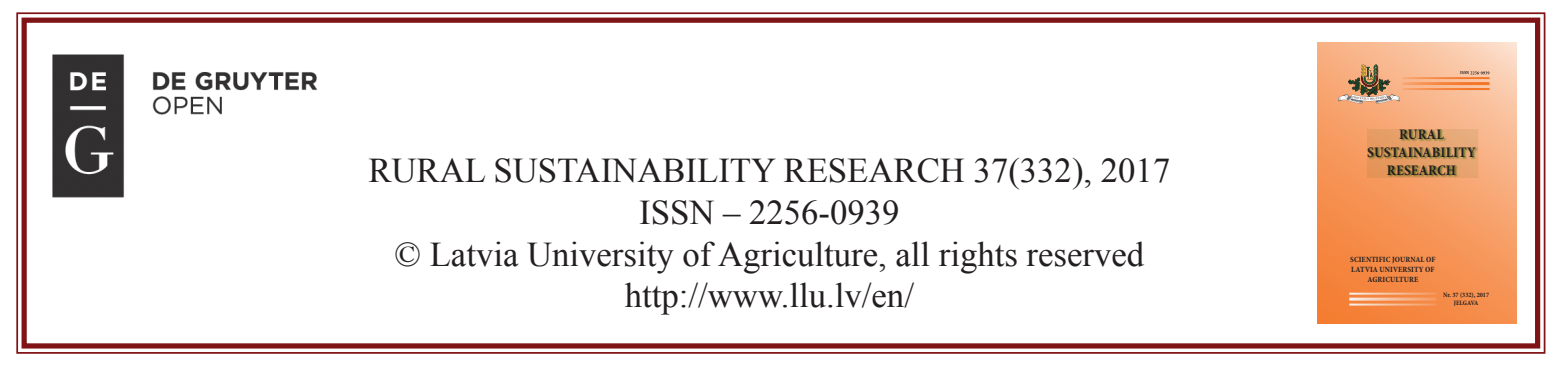

\title{
Rhizobium sp. - a Potential Tool for Improving Protein Content in Peas and Faba Beans
}

\author{
* Alise Šenberga, Laila Dubova, Ina Alsiņa, Liene Strauta \\ Latvia University of Agriculture, Strazdu str. 1, Jelgava, LV-3001
}

\begin{abstract}
Legume seed inoculation prior to sowing is a well-known practice in agriculture. Nitrogen fixation, due to the symbiotic relationship between legumes and rhizobia, improves the productivity of legumes. Rhizobia strain specificity can be observed very often, leading to differences in the total protein content. In this study two faba bean cultivars ('Karmazyn' and 'Bartek') and five pea cultivars ('Retrija', 'Zaiga', 'Lāsma', 'Vitra' and 'Bartek') were tested using various rhizobia strains. In addition, strain effectivity was observed in four different soil types. Overall, the protein content increase was observed after seed inoculation with Rhizobium sp. Rhizobia strain and plant cultivar interaction specification was observed. Plant cultivar appeared to have a decisive role in the formation of protein content when inoculated with Rhizobium sp. From these pilot experiments, it can be concluded that, when choosing Rhizobium $s p$. strains for legume inoculation, soil type also should be considered. Rhizobia has the potential to be used as a commercial preparation intended for increasing legume protein content, alongside with increased legume yield; however, different rhizobia strains should be mixed together to achieve the optimal result.
\end{abstract}

Keywords: rhizobia, legumes, protein content, soil type.

\section{Introduction}

Despite the high nutritious value of legumes, the total yield of beans and peas worldwide has decreased over the past decade. At the same time, the use of peas in agriculture in Europe has increased by $16 \%$ (calculated using data from FAOSTAT; Food and Agriculture Organization of the United Nations, 2016). It is known that legume growth is improved because of their ability to fix nitrogen from the atmosphere, due to their symbiotic relationship with rhizobia bacteria. The symbiotic relationship between legumes and rhizobia benefits also the next crops, as the nitrogen level in soil is enhanced, this way eliminating the need for chemical fertilizers (Deshpande \& Deshpande, 1991; Lindström et al., 2010; Voisin et al., 2014). As the role of rhizobia is very crucial when growing legumes, research on this subject is of great importance.

Legume yield increase is not always the main factor, when looking at the crop productivity. Improvement of food and feed quality over quantity should be considered more, especially in the developed countries. High protein content is one of the main reasons why legumes are such an important crop in agriculture (Voisin et al., 2014). Protein content, together with plant yield and seed weight is an integral part of food and fodder; therefore, we should look at the protein content in legumes and the possibilities to increase it by using biological agents like rhizobia.

Legumes tend to produce as many seeds as possible, notwithstanding the available nitrogen level. This might be done at the expense of protein content of the seed. Protein content, together with plant yield and seed weight, increases in legume seeds with the increase in the availability of nitrogen in the root zone. Increased protein content can be achieved by using nitrogen fertilizers or through seed inoculation with the appropriate strains of rhizobia (Ahmed, 2013; Ahmed et al., 2007; Aslam et al., 2010; Elsheikh \& Elzidany, 1997; Hadi \& Elsheikh, 1999; Kantar et al., 2003; Miller, Kaiser, \& Ogle, 2010; Minta \& Tsige, 2014; Rasool, Tatla, \& Ali, 2006; Zahran, 1999). Several environmental factors affect Rhizobium $s p$.

\footnotetext{
* Corresponding Author's email: alise.senberga@1lu.lv
} 
performance, including temperature and soil quality (Albareda, Rodríguez-Navarro, \& Temprano, 2009; Boonkerd \& Weaver, 1982; Kirova, Ananieva, \& Tzvetkova, 2013; Zahran, 1999), thereby these factors indirectly affect protein content of legume seeds.

It has been suggested that legume yield and and the protein content stored in legume seeds increase depending on the genotype of Rhizobium sp. strain used for inoculation (Ahmed et al., 2007; Bourion et al., 2007; Saleh, Zaman, \& Kabir, 2013). Commercial rhizobium inoculants are available, specially selected to match the specific species to reach the optimal nitrogen fixation activity (Lindström et al., 2010). Although legume seed inoculation with rhizobia prior sowing is a long-practiced method in Latvia, in the recent years a question about differences in strain efficiency within the same species of rhizobia has been raised; therefore, several Rhizobium $s p$. strains that have been isolated in Latvia, were tested. The aim of this study was to compare these strains, using protein content as a measurement of strain efficiency. Rhizobium $s p$. strain efficiency was tested on two bean cultivars and four pea cultivars to test whether the same bacterial strain retains its efficiency between cultivars and between different genera. In addition, three different soil types were pilot-tested to apprehend the impact of this environmental factor on strain efficiency.

\section{Materials and Methods}

Experimental Conditions

Experiments were carried out at the Latvia University of Agriculture, Institute of Soil and Plant Sciences. Four experimental fields with different mineral element (Table 1) and granulometric content (Table 2) were used: loamy sand (Soil A), peat (Soil B), sand (Soil C) and another sand field (Soil D). Soil samples were sent for mineral element and granulometric content analyses to the Institute of Biology, University of Latvia. Soil samples were airdried and extracted using $1 \mathrm{M} \mathrm{HCl}$ (Riņkis \& Ramane, 1989).

\section{Rhizobium sp. Strains}

Rhizobium $s p$. strains used for seed inoculation were obtained from the Collection of Rhizobia of Latvia University of Agriculture. Strains RP023, RP202, RP001 and RP003 have been isolated from Pisum sp., but RV110, RV407, RV505 from Vicia faba. All strains used are streptomycin resistant.

\section{Plant Material}

Faba bean cultivars 'Bartek' and 'Karmazyn', obtained from Torseed $\AA$ (Poland), and pea cultivars 'Retrija', 'Bruno', 'Vitra', 'Lāsma' and 'Zaiga', obtained from the collection of Institute of Agricultural Resources and Economics (Latvia), were used in experiments.

Before sowing, seeds of experimental plants were soaked in rhizobia suspension with a concentration of

Table 1

Mineral element content (in $1 \mathrm{M} \mathrm{HCl} \mathrm{solution,} \mathrm{mg} \mathrm{L}^{-1}$ ) of the four different soil types used in this study, where "Soil A" - loamy sand, "Soil B" - peat, "Soil C" - sand, "Soil D" - sand

\begin{tabular}{|l|c|c|c|c|c|c|c|c|c|c|c|c|}
\hline & N & P & K & Ca & Mg & S & Fe & Mn & Zn & Cu & Mo & B \\
\hline Soil A & 78 & 523 & 170 & 161450 & 3850 & 65 & 1920 & 170 & 10.5 & 6.5 & 0.08 & 0.4 \\
\hline Soil B & 62 & 959 & 155 & 11450 & 2970 & 23 & 1080 & 160 & 26.0 & 8.5 & 0.06 & 0.8 \\
\hline Soil C & 94 & 916 & 170 & 3365 & 465 & 11 & 1220 & 185 & 16.5 & 10.0 & 0.09 & 0.5 \\
\hline Soil D & 66 & 267 & 81 & 1275 & 160 & 8 & 375 & 17 & 4.5 & 1.6 & 0.04 & 0.2 \\
\hline
\end{tabular}

Granulometric content of the four different soil types used in this study, where "Soil A" - loamy sand, "Soil B" - peat, "Soil C" - sand, "Soil D" - sand

\begin{tabular}{|l|c|c|}
\hline & $\mathbf{p H}_{\mathrm{KCl}}$ & Electrical conductivity (EC), $\mathbf{~ m S ~ c m}^{-\mathbf{1}}$ \\
\hline Soil A & 7.60 & 0.60 \\
\hline Soil B & 6.97 & 0.67 \\
\hline Soil C & 6.70 & 0.38 \\
\hline Soil D & 5.40 & 0.18 \\
\hline
\end{tabular}


Experimental setups of four different pilot experiments (No. 1. - 4.). Properties of soil type (A, B, C, and D) are described in Table 1 and Table 2

\begin{tabular}{|c|c|c|c|c|c|}
\hline \multirow[b]{2}{*}{ No. } & \multirow{2}{*}{$\begin{array}{c}\text { Soil type } \\
(\mathrm{A}, \mathrm{B}, \mathrm{C}, \mathrm{D})\end{array}$} & \multicolumn{2}{|c|}{ Plant Material } & \multicolumn{2}{|c|}{ Rhizobium sp. strains } \\
\hline & & Faba bean cultivars & Pea cultivars & Isolated from $V \cdot f a b a$ & $\begin{array}{l}\text { Isolated from } \\
\text { Pisum sp. }\end{array}$ \\
\hline 1. & $\begin{array}{l}\text { B } \\
\text { C }\end{array}$ & 'Karmazyn' 'Bartek' & - & $\begin{array}{l}\text { RV110 } \\
\text { RV407 } \\
\text { RV505 }\end{array}$ & RP023 \\
\hline 2. & A & - & $\begin{array}{l}\text { 'Retrija', } \\
\text { 'Zaiga', } \\
\text { 'Lāsma', } \\
\text { 'Vitra', } \\
\text { 'Bruno' }\end{array}$ & - & $\begin{array}{l}\text { RP023 } \\
\text { RP202 } \\
\text { RP003 }\end{array}$ \\
\hline 3. & $\mathrm{D}$ & - & $\begin{array}{l}\text { 'Retrija' } \\
\text { 'Zaiga' }\end{array}$ & RV407 & $\begin{array}{l}\text { RP023 } \\
\text { RP003 }\end{array}$ \\
\hline 4. & A & - & 'Vitra' & RV407 & $\begin{array}{l}\text { RP023 } \\
\text { RP001 }\end{array}$ \\
\hline
\end{tabular}

bacteria of $10^{9}$ cells per $\mathrm{mL}$ for $20-30$ minutes. Size of each experimental pot was $1 \mathrm{~m}^{2}$. Experiments were done in 3 replicates.

Experimental design

This experiment serves as a pilot test with the aim to observe the effectivity of above mentioned rhizobia strains. This trial includes four different pilot tests one for faba beans and three for peas (Table 3).

Meteorological Conditions

Vegetation period of 2013 was characterized with warm May (3.6 degrees above the long-term average) and June (2.9 degrees above the average). Temperatures in July and August were close to average data. June, July and August were relatively dry; the precipitation was 71,79 and $86 \%$, respectively, which was less than average long-term data.

Vegetation period of 2014, in comparison with long-term data, had relatively cool June, July and August; temperatures were by $1.7,0.7$ and $0.8^{\circ} \mathrm{C}$, respectively, lower in comparison with average. All vegetation period was characterized with higher precipitation than average (123-220\% from long-term data), but at the beginning of flowering stage, water deficit in the soils (all except soil B) was observed.

Protein Content Determination

Protein content in pea and faba bean seeds was determined using mature, dry seeds. For protein analyses the average sample of all replicates was used. Protein content was determined in two replicas using Kjeldal method (LVS EN ISO 5983-2:2009).

Statistical Analyses

All statistical analyses were done using Excel (Microsoft Corporations, Redmond, Washington,
USA). Obtained data were processed using Analyses of Variance (ANOVA).

\section{Results}

All data obtained in these pilot experiments were analyzed using ANOVA to examine the interaction of strains and different faba bean or pea cultivars. No statistically significant differences were observed between different rhizobia strains. Only trends of some more superior strains over other could be observed. The error bars used in the figures represent the errors within the method of protein content determination.

Protein Content in Faba Beans

On average, the protein content of faba bean seeds grown in soil C was $12.8 \%$ higher compared to protein content in seeds of faba beans grown in soil B (Figure 1). Seeds of faba bean cultivar 'Bartek' contained an average of $31.6 \%$ protein, while 'Karmazyn' seeds contained an average of $28.6 \%$ protein. Analyses of the average data showed significant $(p<0.05)$ impact of faba bean cultivars on the content of protein in seeds (data not shown). The most effective strain in terms of protein content for faba beans appeared to be RV110 for cultivar 'Karmazyn' and RP023 for cultivar 'Bartek'. The efficiency of these strains differs depending on the soil variant. For instance, 'Karmazyn' inoculated with strain RV505 in soil B shows higher protein content than control, but in soil $\mathrm{C}$ the amount of protein content is at the same level as control plants. Contrary, 'Karmazyn' inoculation with strain RV110 results in protein content as in control plants in soil $\mathrm{B}$, while the protein content exceeds control level if 


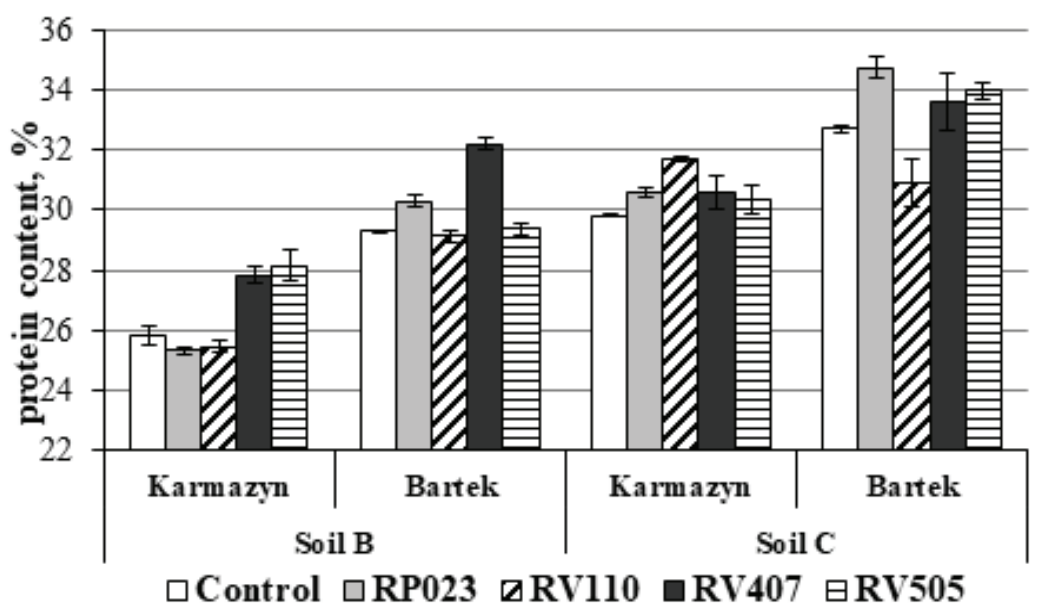

Figure 1. Protein content (\%) in mature, dry seeds of faba beans, depending on the cultivar ('Karmazyn' and 'Bartek') and Rhizobium sp. strain (RP023, RV110, RV407, RV505) used for inoculation. Control - plants without inoculation. The level of protein content (\%) is referred to the average sample from all the replicates.

Soil B - peat, $\mathrm{pH}$ 6.97; Soil C - sand, $\mathrm{pH}$ 6.7. Error bars represent the error within the protein content determination method.

grown in soil $\mathrm{C}$ (Figure 1). The most effective strain in soil B was RV407.

\section{Protein Content in Peas}

Protein content in peas was tested in soil A in two separate trials (Figure 2, Figure 4) and in soil D (Figure 3). In soil A (Figure 2) protein content in the seeds of peas fluctuated from 22.3 to $27.8 \%$. Significant effect of the cultivar on the protein content in peas was observed. The highest amount of protein was seen in the seeds of cultivar 'Vitra' - with an average of $26.2 \%$, followed by cultivar 'Bruno' and 'Zaiga' with 25.6 and $25.0 \%$, respectively (Figure2). The lowest protein content was observed in the seeds of 'Retrija'. Seed inoculation with rhizobia strain RP023 or RP003 resulted in a higher protein content tendency, compared to strain RP202 for cultivars 'Zaiga' and 'Vitra'. However, 'Lāsma' showed the highest protein content if treated with RP202 or RP023, compared to RP003 (Figure 2). Unfortunately, this pilot experiment was designed to test the protein content in different pea cultivars inoculated with one of three rhizobia strains, and did not include a control variant without any treatment.

Two pea cultivars, 'Retrija' and 'Zaiga', were tested in soil D. In this trial test pea seeds were inoculated with three different rhizobia strains prior

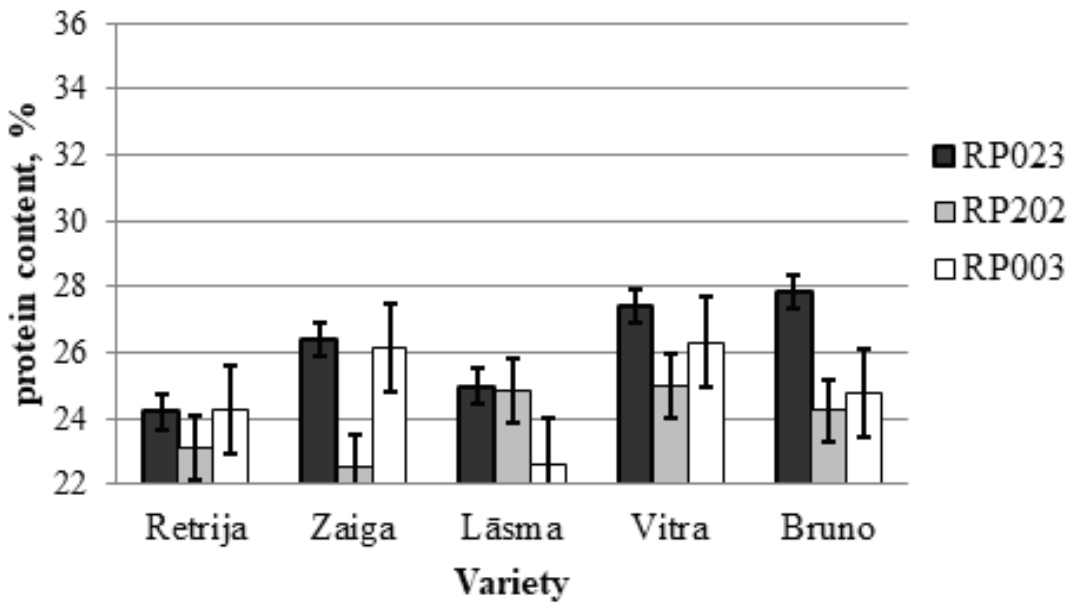

Figure 2. Protein content (\%) in mature, dry seeds of peas grown in soil A (loamy sand, pH 7.6), depending on bean cultivar ('Retrija', 'Zaiga', 'Lāsma', 'Vitra', 'Bruno') and Rhizobium sp. strain (RP023, RP202, $\mathrm{RP003})$ used for inoculation. The level of protein content (\%) is referred to the average sample from all the replicates. Error bars represent the error within the protein content determination method. 


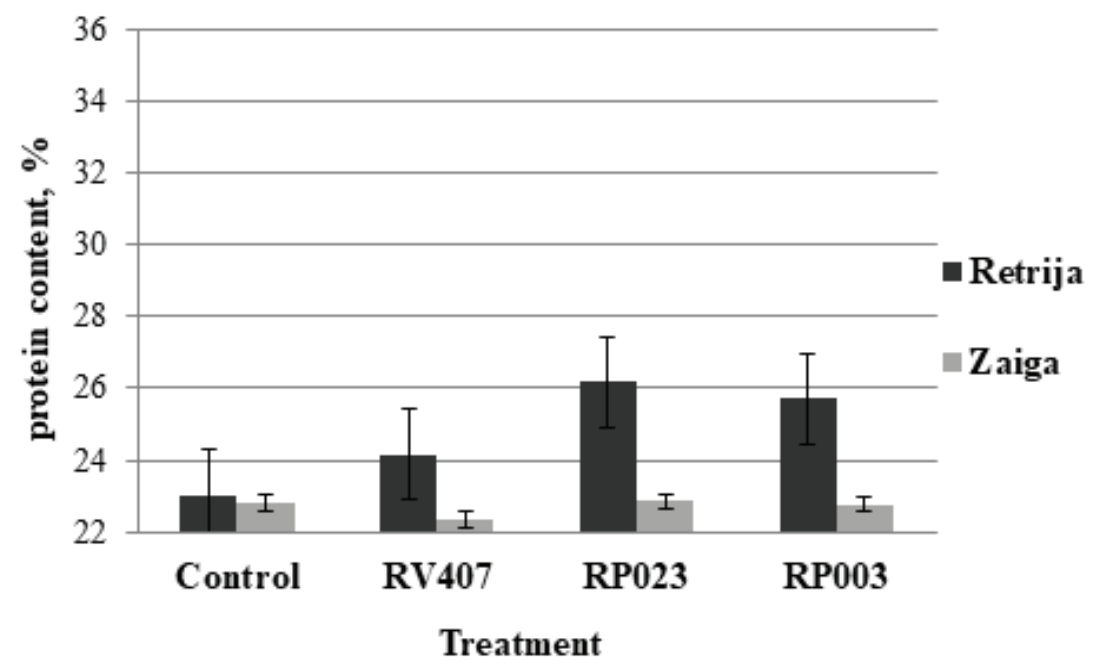

Figure 3. Protein content (\%) in mature, dry seeds of peas grown in soil D (sand, pH 5.4), depending on pea cultivar ('Retrija' and 'Zaiga') and Rhizobium sp. strains (RV407, RP023, RP003) used for inoculation.

Plants without bacteria inoculation served as a control. The level of protein content (\%) is referred to the average sample from all the replicates. Error bars represent the error within the protein content determination method.

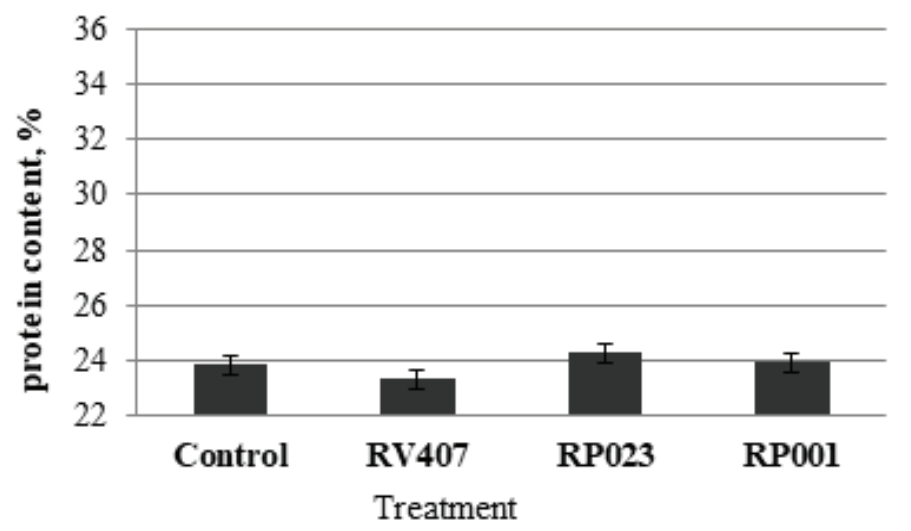

Figure 4. Protein content (\%) in mature, dry seeds of pea cultivar 'Vitra' grown in soil A (loamy sand, $\mathrm{pH}$

7.6), depending on Rhizobium sp. strains (RV407, RP023, RP001) used for inoculation. Plants without treatment served as a control. The level of protein content $(\%)$ is referred to the average sample from all the replicates. Error bars represent the error within the protein content determination method.

sowing. 'Retrija' reached the highest protein content in soil D when treated with strain RP023, while 'Zaiga' had no significant effect of rhizobia treatment, compared with control (Figure 3).

An additional pilot test was done using pea cultivar 'Vitra', testing the effectivity of three different rhizobia strains in soil A. The highest protein content for 'Vitra' in this experiment was obtained when inoculated with RP023. Inoculation with strain RV407 resulted in a decreased protein content (Figure 4).

Results from these pilot trials indicate faba bean and pea seed protein content dependence on mainly the cultivar of the species. Rhizobia strain used for seed inoculation and the soil type show a trend of possible impact on protein content.

In all trial fields, including the control plants, the presence of nodulation could be observed on the root zone.

\section{Discussion}

\section{Protein Content in Faba Beans}

Obtained results showed that protein content in faba beans is affected at some level by all three investigated factors - plant cultivar, Rhizobium $s p$. strain and soil properties. However, as stated before, no significant differences could be observed, only a 
trend that indicates a possible strain specificity within the species. In most variants, higher protein content was detected in plants that were grown in soil C, which contained less organic and mineral elements. Rhizobia strain efficiency showed dependence on soil properties. For instance, 'Bartek' plants treated with strain RP023 showed lower efficiency in soil B, compared to strain RV407, while exceeding RV407 efficiency in soil C. The differences in protein content can mostly be explained with the cultivar used. For instance, in soil B, both 'Karmazyn' and 'Bartek' show higher protein content compared to control if treated with strain RV407; however, 'Bartek' shows higher protein content in general, if compared to 'Karmazyn' in both - soil B and soil C (Figure 1). Ability of rhizobia to increase the protein content in faba bean seeds has been observed previously (Elsheikh \& Elzidany, 1997). Soybean, belonging to the same Fabaceae family as faba bean, also shows higher protein content, when seeds are inoculated with rhizobia before sowing (Ahmed, 2013). The highest protein content, however, has shown to be achieved, if rhizobia inoculation is supplemented with nitrogen fertilizer (Elsheikh \& Elzidany, 1997). It has been shown that chickpea seeds under nitrogen fertilizer treatment show the highest protein content (Aslam et al., 2010). However, protein content in seeds was still higher if treated with rhizobia compared to control variant, therefore authors suggest supplementing seed inoculation with Rhizobium $s p$. with the use of nitrogen fertilizer, to achieve the optimal protein content. In our pilot study, the aim was to select the most efficient rhizobia strain out of the rhizobia collection, and nitrogen fertilizer was not included in the study. However, for further strain efficiency test, nitrogen fertilizer should be included.

Protein Content in Peas

Contrary to the results obtained with faba beans, no significant effect of soil properties was observed in the case of peas (Figure 2, Figure 3, Figure 4). However, a trend of host specificity was visible. Rhizobia strains isolated from pea nodules (RP023, RP202, RP001 and RP003) showed higher protein content by more than one percentage point in comparison with isolates from bean nodules (RV110, RV407, RV505; Figure 2, Figure 3, Figure 4). In soil A (Figure 2, Figure 4) and soil D (Figure 3 ) the best results were obtained using rhizobia strain RP023. Strain RP202 was the least effective for all analyzed cultivars. Overall, RP023 showed the most promising results for all cultivars tested in both tested soil types.

An interaction (or a trend of interaction) between cultivar, rhizobia strain, and soil could be detected. An increase of protein content in 'Retrija' seeds could be observed if treated with rhizobia in both, soil A (Figure 2) and soil D (Figure 3); 'Zaiga' showed no response to inoculation with rhizobia in soil D (Figure 3 ), while in soil A (Figure 2) differences in protein content could be observed after inoculation with rhizobia.

Previous study has shown that the choice of pea cultivar is of great importance, as the variation of protein content depends on the genetic information encoded in the plant (Bourion et al., 2007). This type of variation can be also observed in the current study, when under the same conditions and treatments, differences in protein content are due to the pea cultivar (Figure 2, Figure 3). In addition, it has been shown that mature seed protein content can be directly related to the use of rhizobia, as higher protein content has been observed in peas with higher nodulation of the roots (Bourion et al., 2007). Our trial study shows a trend of strain specificity, when inoculating peas. Similar results have been shown previously, when certain Rhizobium $s p$. strains used for seed inoculation show significantly higher protein yield in mature seeds (Ahmed et al., 2007). Like peas (Bourion et al., 2007) also in chickpea plants a correlation between increased nodulation and higher protein content of seeds can be observed (El Hadi \& Elsheikh, 1999). This study (El Hadi \& Elsheikh, 1999), similar to our study, shows Rhizobium sp. strain specificity. Contrary to it, a study on chickpeas (Aslam et al., 2010) did not find significant differences between different Rhizobium sp. strains used for inoculation.

Although no significant differences were detected between the different rhizobia strains used for inoculation, in many cases a clear trend was visible, where some strains seem to be more superior over others. This trend is worth to explore in further experiments, increasing the replication number. Interestingly, some rhizobia strains reach higher activity in one soil type, while showing a decreased activity in other. Furthermore, there was not one clear soil type favored by all rhizobia strains, in fact, some strains showed better results in one soil type, while other strains showed the same trend of higher protein content in different soil type.

Previous studies (Aslam et al., 2010; El Hadi \& Elsheikh, 1999) suggest specific Rhizobium $s p$. strain use; however, this is not the best solution for the use in commercial agriculture. To overcome soil specificities and increase concurrence ability with the native rhizobia, it can be suggested that a mixture of Rhizobium sp. strains for faba bean and pea inoculation is used. This mixture could be potentially developed into an effective commercial product used in agriculture. It has been proposed previously that plant exposure to a higher rhizobia strain diversity 
can lead to formation of a successful plant-rhizobia symbiosis (Lindström et al., 2010).

\section{Conclusions}

Protein content depends on plant genus and cultivar. For faba beans, higher protein content in seeds was detected in cultivar 'Bartek' - average of $31.6 \%$, while 'Karmazyn' seeds contained an average of $28.6 \%$ protein. The highest amount of seeds' protein was in the pea of cultivar 'Vitra' - with an average of $26.2 \%$, followed by cultivar 'Bruno' and 'Zaiga' with 25.6 and $25.0 \%$, respectively. The lowest protein content was observed in the seeds of 'Retrija' $-22.3 \%$.

For faba beans interaction of rhizobia strain and soil was observed. The most effective strain in peat soil was RV407. In sandy soil interactions between soil, Rhizobium sp. strain and faba bean cultivar could be observed. The most effective strain in terms of protein content for faba beans appeared to be RV110 for cultivar 'Karmazyn' and RP023 for cultivar 'Bartek'.

For peas, no significant effect of cultivar or soil type was observed. Rhizobia strains isolated from pea nodules (RP023, RP202, RP001 and RP003) showed higher protein content by more than one percentage point in comparison with isolates from bean nodules.

To ensure an effective symbiosis between host legumes and inoculant, the use of Rhizobium sp. strains isolated from the same host genus is recommended.

To obtain the most effective symbiotic system in different soil types, an association from rhizobia strains can be used.

\section{References}

1. Ahmed, R., Solaiman, A.R.M., Halder, N.K., Siddiky, M.A., \& Islam, M.S. (2007). Effect of inoculation methods of Rhizobium on yield attributes, yield and protein content in seed of pea. J. Soil. Nature, 1(3), 30-35.

2. Ahmed, F.E. (2013). Interactive effect on nitrogen fertilization and Rhizobium inoculation on nodulation and yield of soybean (Glycine max L. Merrill). G.J.B.A.H.S., 2(4), 169-173.

3. Albareda, M., Rodríguez-Navarro, D.N., \& Temprano, F.J. (2009). Soybean inoculation: Dose, $\mathrm{N}$ fertilizer supplementation and rhizobia persistence in soil. Field Crops Research, 113(3), 352-356. DOI: 10.1016/j.fcr.2009.05.013.

4. Aslam, M., Ahmad, H.K., Ayaz, M., Ahmad, E., Sagoo, A. G., Ullah, I., Hussain, A., \& Manzoor, M. (2010). Nodulation, grain yield and grain protein contents as affected by Rhizobium inoculation and fertilizer placement in chickpea cultivar Bittle-98. Sarhad J. Agric., 26(4), 467475.

5. Bourion, V., Laguerre, G., Depret, G., Voisin, A.S., Salon, C., \& Duc, G. (2007). Genetic variability in nodulation and root growth affects nitrogen fixation and accumulation in pea. Annals of Botany, 100(3), 589-598. DOI: 10.1093/aob/ mcm147.

6. Boonkerd, N., \& Weaver, R.W. (1982). Survival of cowpea rhizobia in soil as affected by soil temperature and moisture. Applied and Environmental Microbiology, 43(3), 585-589.

7. Deshpande, U.S., Deshpande, S.S. (1991). Legumes. In D.K. Salunkhe \& S.S. Deshpande (Eds.), Foods of plant origin: production, technology, and human nutrition (pp. 137300). Springer Science \& Business Media: Van Nostrand Reinhold.

8. Elsheikh, E.A.E., \& Elzidany A.A. (1997). Effect of Rhizobium inoculation, organic and chemical fertilizers on proximate composition, in vitro protein digestibility, tannin and sulphur content of faba beans. Food Chemistry, 59(1), 4145. DOI: 10.1016/S03088146(96)00046-5.

9. Food and Agriculture Organization of the United Nations. Food and Agricultural commodities production. Retrieved February 20, 2016, from http://faostat.fao.org/site/339/default.aspx

10. El Hadi, E.A., \& Elsheikh, E.A.E. (1999). Effect of Rhizobium inoculation and nitrogen fertilization on yield and protein content of six chickpea (Cicer arietinum L.) cultivars in marginal soils under irrigation. Nutrient Cycling in Agroecosystems, 54(1), 57-63. DOI: 10.1023/A:1009778727102.

11. Kantar, F., Elkoca, E., Öğütcü, H., \& Algur, Ö.F. (2003). Chickpea yields in relation to Rhizobium inoculation from wild chickpea at high altitudes. Journal of Agronomy and Crop Science, 189(5), 291-297. DOI: 10.1046/j.1439037X.2003.00046.x.

12. Kirova, E., Ananieva, K., \& Tzvetkova, N. (2013). Soybean plants with symbiotic N2 fixation are more resistant to salt stress than nitrate-fed plants. Genetics and Plant Physiology, 3(1-2), 65-76.

13. Lindström, K., Murwira, M., Willems, A., Altier, N. (2010). The biodiversity of beneficial microbe-host mutualism: the case of rhizobia. Research in Microbiology, 161, 453-463. DOI: 10.1016/j.resmic.2010.05.005.

14. Miller, R., Kaiser, J., \& Ogle, D.G. (2010). Technical Note No. 26 - Legume Inoculation. Idaho Plant Materials, Utah, 15. 
15. Minta, M., \& Tsige, A. (2014) Effect on Rhizobium inoculation on herbage yield, quality and nitrogen fixation of annual forage legumes on nitisols in central highlands of Ethiopia. Acta Advances in Agricultural Sciences, 2(10), 29-48.

16. Rasool, G., Tatla, Y.H., \& Ali, M.A.A. (2006). Rhizobium preparāta un mēslojuma ietekme uz mungo pupiņu ražu. (Effect of Rhizobium inoculation and fertilizer application on mungbean yield). African Journal of Agricultural Research, 44(3), 209-214.

17. Rin̦kis, G., Ramane, H. (1989). Kā barojas augi (Plant Nutrition). Rīga: Avots. (in Latvian).

18. Saleh, M.A., Zaman, S., \& Kabir, G. (2013). Yield response of black gram to inoculation by different Rhizobium strains using various types of adhesives. Asian Journal of Biological Sciences, 6(3), 181-186. DOI: 10.3923/ajbs.2013.181.186.

19. Voisin, A.S., Guéguen, J., Huyghe, C., Jeuffroy, M.H., Magrini, M.B., Meynard, J.M., Mougel, C., Pellerin, S., \& Pelzer, E. (2014). Legumes for feed, food, biomaterials and bioenergy in Europe: a review. Agronomy for Sustainable Development, 34(2), 361-380. DOI: 10.1007/ s13593-013-0189-y.

20. Zahran, H.H. (1999). Rhizobium-legume symbiosis and nitrogen fixation under severe conditions and in an arid climate. Microbiology and Molecular Biology Reviews, 63(4), 968989.

\section{Acknowledgments}

This project is supported by EU $7^{\text {th }}$ frame EUROLEGUME project (Enhancing of legumes growing in Europe through sustainable cropping for protein supply for food and feed). 